\title{
CHARACTERIZATION OF L-GLUTAMIC ACID TRANSPORT BY GLIOMA CELLS IN CULTURE: EVIDENCE FOR SODIUM- INDEPENDENT, CHLORIDE-DEPENDENT HIGH AFFINITY INFLUX ${ }^{1}$
}

\author{
ROBERT A. WANIEWSKI ${ }^{2}$ AND DAVID L. MARTIN \\ Center for Laboratories and Research, New York State Department of Health, Albany, New York 12201
}

Received January 23, 1984; Revised March 8, 1984; Accepted March 12, 1984

\begin{abstract}
The transport of radiolabeled L-glutamic acid by LRM55 glioma cells in culture was examined. Time course studies indicated that $\mathrm{L}-\left[{ }^{3} \mathrm{H}\right]$ glutamic acid is rapidly accumulated, and then ${ }^{3} \mathrm{H}$ is lost from the cell, presumably in the form of glutamate metabolites. Kinetic analysis of L-glutamate uptake provided evidence for two components of transport. A low affinity component was found to persist at 0 to $4^{\circ} \mathrm{C}$ and was not saturable, influx being proportional to the substrate concentration. A high affinity component, resolved by subtraction of the influx at 0 to $4^{\circ} \mathrm{C}$, followed Michaelis-Menten kinetics having a $K_{m}$ of $123 \mu \mathrm{M}$ and a $V_{\max }$ of $2.99 \mathrm{nmol} /$ $\mathrm{min} / \mathrm{mg}$ of protein. The transport system was highly substrate-specific: At least 27 -fold larger concentrations of the most potent analogues-cysteic acid, cysteine sulfinic acid, and L-aspartic acid-were required to compete effectively with glutamate. Second, the system was not severely affected by exposure to inhibitors of oxidative phosphorylation or $\gamma$-glutamyltranspeptidase. Third, only $65 \%$ of the high affinity uptake was dependent upon the presence of sodium, the other $35 \%$ being dependent upon chloride. These observations were supported by the findings that uptake was only partially inhibited by ouabain and quite effectively reduced by several inhibitors of chloride transport. The results of this study provide information on the properties of low affinity glutamate transport, as well as the first description of sodium-independent, chloride-dependent high affinity glial transport. The high affinity component of influx is stimulated by elevated potassium and inhibited by several pharmacological agents. The sodium independence of a significant proportion of high affinity glutamate transport suggests that glutamate binding studies done in sodium-free medium with intact cells may be confounded by a considerable amount of intracellular uptake.
\end{abstract}

The transport systems of glial cells provide one means of clearing the extracellular space of potentially neuroactive substances. Specific, high affinity transport systems have been identified in glia for several putative amino acid neurotransmitters, including GABA, glycine, taurine, aspartic acid, and glutamic acid (Henn and Hamberger, 1971; Schrier and Thompson, 1974). The high affinity glutamate transport system is sodium-dependent (Henn et al., 1974; Schousboe et al., 1977) and mediates net transport rather than homoexchange (Hertz et al., 1978).

Glial transport of $\mathbf{L}$-glutamic acid is particularly important because of the many roles of this amino acid in the nervous system; it serves as a precursor of GABA, as a key substrate in metabolism, and is a potent neuroexcitatory agent. The glial localization of glutamine synthetase (Norenberg, 1979) and the neuronal location of glutamate decarboxylase (GAD) (Ribak et al., 1976) and glutaminase (Bradford et al., 1978) indicate that

\footnotetext{
${ }^{1}$ This work was supported by National Institutes of Health Research Grant NS16735 to D. L. M. from the National Institute of Neurological Disorders and Stroke, Public Health Service/Department of Health and Human Services, and by the New York State Department of Health. We wish to thank Harry Miller for his excellent technical assistance.

${ }^{2}$ To whom correspondence should be addressed.
}

glutamate is metabolized quite differently in these two cell types. It is thought that the distribution of glutamate and glutamine between the neuronal and glial compartments in the brain is controlled by the so-called "glutamine cycle" (Van den Berg and Garfinkel, 1971; Balazs et al., 1973). In this cycle extracellular glutamate and GABA are accumulated by glia, converted to glutamine, and then returned to the neurons from which they were originally released. Recent evidence (Gordon and Balazs, 1983) indicates that in the rat cerebellum glutamate is taken up primarily by astrocytes and only slightly by granule cells. Indeed, it has been suggested that, throughout the nervous system, glia rather than neurons are the cells that principally accumulate glutamate (McLennan, 1976; Currie and Kelly, 1981). It is possible that the glial transport of glutamate is a well regulated step in the glutamine cycle. Furthermore, the extensive accumulation of glutamate by glia might be expected to produce shifts in intracellular ion concentrations since sodium has been shown to be co-transported with glutamate (Schousboe et al., 1977; Stallcup et al., 1979). The method of tissue culture with glial cells was selected as the best available system for examining the properties of glutamate uptake and ion co-transport because it allows the study of a homogeneous population of intact cells in situ while manipulating the extracellular environment. The LRM55 glioma cell line was used for these studies since previously it had been shown to have a 
number of characteristics of normal glia, including carbonic anhydrase activity, astrocytic morphology, ion fluxes (Wolpaw and Martin, 1982a), high affinity uptake of other amino acids, and no GAD activity (Martin and Shain, 1979). We now report our findings on the properties of glutamate transport by LRM55 cells and provide evidence for sodium-independent, chloride-dependent high affinity $\mathrm{L}-\left[{ }^{3} \mathrm{H}\right]$ glutamate uptake.

\section{Materials and Methods}

LRM55 glioma cells, derived from a rat spinal astrocytoma (Morantz et al., 1978; Martin and Shain, 1979), were maintained in culture in 100-mm plastic Petri dishes and fed Ham's F12 medium (Vogel et al., 1972 ) supplemented with $2.5 \%$ fetal calf serum. For individual experiments, approximately 1 to $2 \times 10^{4}$ cells from passages 7 through 20 were transferred to each well of 24 -well culture trays (Costar, no. 3524) and maintained for 5 to 7 days before use. Cells formed a confluent monolayer with an estimated density of $10^{6}$ cells/well and an average protein content of approximately $100 \mu \mathrm{g} /$ well at the end of this time. Uptake procedures were identical to those described previously (Martin and Shain, 1979). Briefly, wells were rinsed three times with $1 \mathrm{ml}$ of HEPES-buffered ( $\mathrm{pH} 7.3$ ) Hanks' balanced salt solution (HBHS). One milliliter of HBHS was left in each well to allow the cells to equilibrate. After 15 to $30 \mathrm{~min}$ the medium was replaced with $200 \mu$ l of HBHS containing various drugs in experiments requiring pre-incubation or with medium containing $\mathrm{L}-\left[{ }^{3} \mathrm{H}\right]$ glutamic acid (with test substances in inhibition experiments). Cells were incubated for the indicated time, rinsed four times with $1 \mathrm{ml}$ of fresh HBHS within $6 \mathrm{sec}$, and then dissolved in $0.5 \mathrm{ml}$ of $0.4 \mathrm{~N} \mathrm{NaOH}$. At least three similarly treated wells from each 24-well tray were analyzed for protein content with BSA standards by the method of Lowry et al. (1951). After standing overnight to ensure complete dissolution of the cells, the extracts were transferred with two $0.5-\mathrm{ml}$ water washes to a scintillation vial, and the radioactivity was determined.

$\mathbf{L}-\left[{ }^{3} \mathrm{H}\right]$ Glutamic acid (specific activity $=21.6 \mathrm{Ci} / \mathrm{mmol}$, New England Nuclear) was purified by thin layer chromatography by the method of Miller and Martin (1972). The purity of each lot varied between 80 and $95 \%$. Unlabeled L-glutamic acid monosodium or monopotassium salt (Sigma Chemical Co.) was added to the $\mathrm{L}-\left[{ }^{3} \mathrm{H}\right]$ glutamate to produce the desired substrate concentration.

To estimate the incorporation of label into protein, cells were rinsed with fresh medium and then extracted with $5 \%$ trichloroacetic acid (TCA). The TCA-soluble and -insoluble components were separated and analyzed by scintillation counting to determine the distribution of the ${ }^{3} \mathrm{H}$ label after uptake.

Studies of ion co-transport with glutamate were performed with tracer amounts of either ${ }^{22} \mathrm{Na},{ }^{36} \mathrm{Cl}$, or ${ }^{42} \mathrm{~K}$ (New England Nuclear) added to the normal HBHS. To measure chloride influx during glutamate uptake, cells were incubated for $2 \mathrm{~min}$ in media containing ${ }^{36} \mathrm{Cl}$ with or without $5 \mathrm{mM} \mathrm{L}$-glutamate. Cells were rinsed, and the intracellular ${ }^{36} \mathrm{Cl}$ content was determined. A similar experiment was carried out in ${ }^{42} \mathrm{~K}$-labeled media with varying concentrations of $\mathrm{L}$-glutamate ( $25 \mu \mathrm{M}$ to $5 \mathrm{mM}$ ) to measure potassium influx during glutamate uptake. After 5 min cells were rinsed, and the intracellular ${ }^{42} \mathrm{~K}$ was determined. To measure the efflux of potassium during glutamate uptake, cells were preloaded for $1 \mathrm{hr}$ in ${ }^{42} \mathrm{~K}$-containing media. The media were then replaced with normal media containing $\mathrm{L}$-glutamate at the same concentrations used for ${ }^{42} \mathrm{~K}$ influx. The media were removed after $5 \mathrm{~min}$ and analyzed for ${ }^{42} \mathrm{~K}$. The co-transport of sodium and glutamate was measured by pre-incubating cells for $30 \mathrm{~min}$ in ${ }^{22} \mathrm{Na}$-containing media in the presence or absence of $5 \mathrm{~mm}$ ouabain. $\mathrm{L}-\left[{ }^{3} \mathrm{H}\right]$ Glutamate (final concentration: 50,500 , or $5000 \mu \mathrm{M}$ ) was then added directly to the medium in the wells, and cells were incubated for an additional 5 min. The cells were then rinsed and analyzed for both ${ }^{3} \mathrm{H}$ and ${ }^{22} \mathrm{Na}$ content.

Sodium chloride was replaced with choline chloride or lithium chloride to study the effects of sodium on $\left[{ }^{3} \mathrm{H}\right]$ glutamate uptake. Chloride concentrations were varied by substituting sodium isethionate or sodium gluconate for sodium chloride. Isosmotic sucrose was substituted for sodium chloride to produce media in which both sodium and chloride were varied. In these media and the corresponding controls, magnesium chloride, magnesium sulfate, and calcium chloride werc replaced with magnesium and calcium gluconate. Sulfate was eliminated because of the extensive transport of this anion in LRM55 cells (Wolpaw and Martin, 1982b). The $\mathrm{pH}$ of each medium was adjusted with potassium hydroxide. The added potassium concentration $(3.5 \mathrm{mM})$ was not enough to depolarize the cells (Seligmann, 1978). All other components of the media were identical to those in the HBHS normally used. In experiments in which potassium was altered, this ion was varied with sodium to maintain the same total concentration of sodium plus potassium.

In experiments with ionically altered media, cells were rinsed three times with the ion-substituted medium and allowed to equilibrate for $30 \mathrm{~min}$. This medium was removed, cells were rinsed two more times, and then uptake was begun by adding $200 \mu \mathrm{l}$ of the same medium containing $\mathrm{L}-\left[{ }^{3} \mathrm{H}\right]$ glutamate. Potassium glutamate was used as the substrate in experiments with sodium-free medium.

Most test compounds were purchased from Sigma Chemical Co. or Aldrich Chemical Co. 4-Acetamido-4'-isothiocyano-2,2'-disulfonic acid stilbene (SITS) and 4,4'-diisothiocyano-2,2' -disulfonic acid stilbene (DIDS) were purchased from Pierce Chemical Co. and stored frozen, protected from light. Ethacrynic acid was a gift from Hoechst Pharmaceuticals. Diazepam was a gift from Hoffmann-La Roche, Inc. All compounds tested were dissolved in HBHS and the pHs adjusted to 7.3 , with the exception of furosemide, which was first dissolved in 50 $\mathrm{mM} \mathrm{NaOH}$ and diluted into $\mathrm{HBHS}$ prior to $\mathrm{pH}$ adjustment.

Statistical analysis of differences between group means was by oneway analysis of variance. When significant differences were found at $p$ $<0.05$, Newman-Keuls multiple range test or Dunnett's test was performed to find where the differences lay (Zar, 1974). In cases where only two groups were compared, the Student's $t$ test was used.

\section{Results}

To determine the optimal time of incubation for initial rate studies of glutamate uptake, LRM55 cells were incubated for various lengths of time with 1,100 , or $1000 \mu \mathrm{M} \mathrm{L} \cdot\left[{ }^{3} \mathrm{H}\right]$ glutamic acid. At all three concentrations the rate of uptake was linear with time only for the first $10 \mathrm{~min}$ (Fig. 1). The distribution of intracellular label between soluble and protein components was also examined by extracting cells with 5\% TCA (Fig. 2). At early times less than $5 \%$ of the intracellular label was in the TCA-precipitable fraction. At later times, however, soluble label was lost from the cells, and the amount of label in the protein became a major part of total intracellular label. Therefore, incubations with $\left[{ }^{3} \mathrm{H}\right]$ glutamate were kept short, and initial velocities were measured after 5 -min incubations. The pre-incubation time and number of rinses were also varied to determine optimal conditions for initial velocity experiments. Varying the pre-incubation time from 0 to $30 \mathrm{~min}$ had no effect

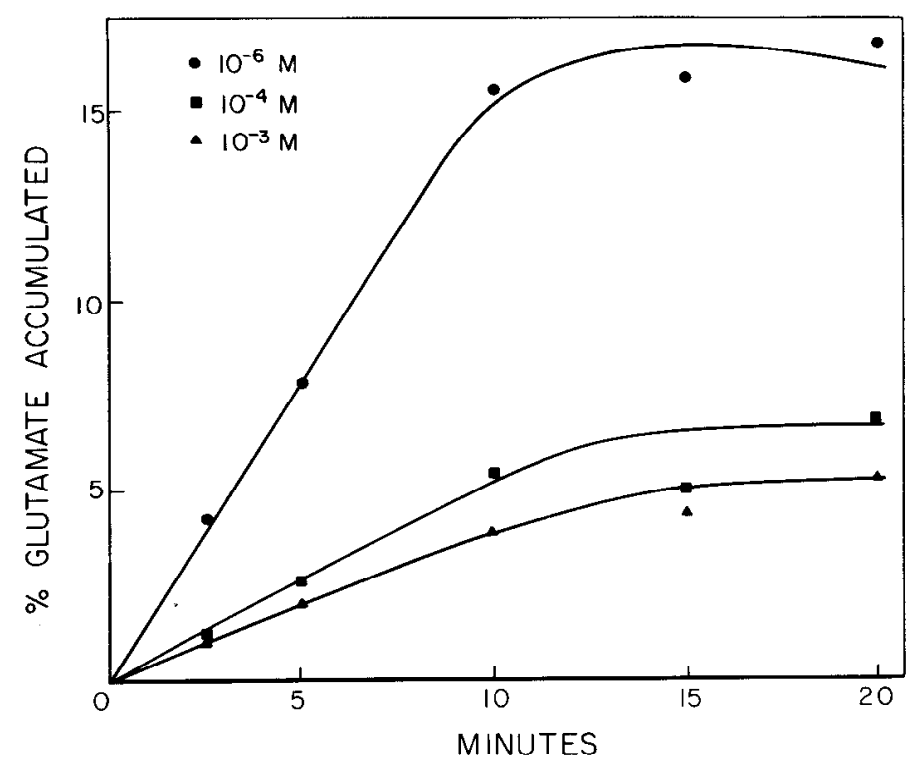

Figure 1. Initial velocity time course for $\mathrm{L}-\left[{ }^{3} \mathrm{H}\right]$ glutamate accumulation at three substrate concentrations. Each point is the mean of two determinations expressed as a percentage of the incubation medium $L$ $\left[{ }^{3} \mathrm{H}\right]$ glutamate accumulated. 


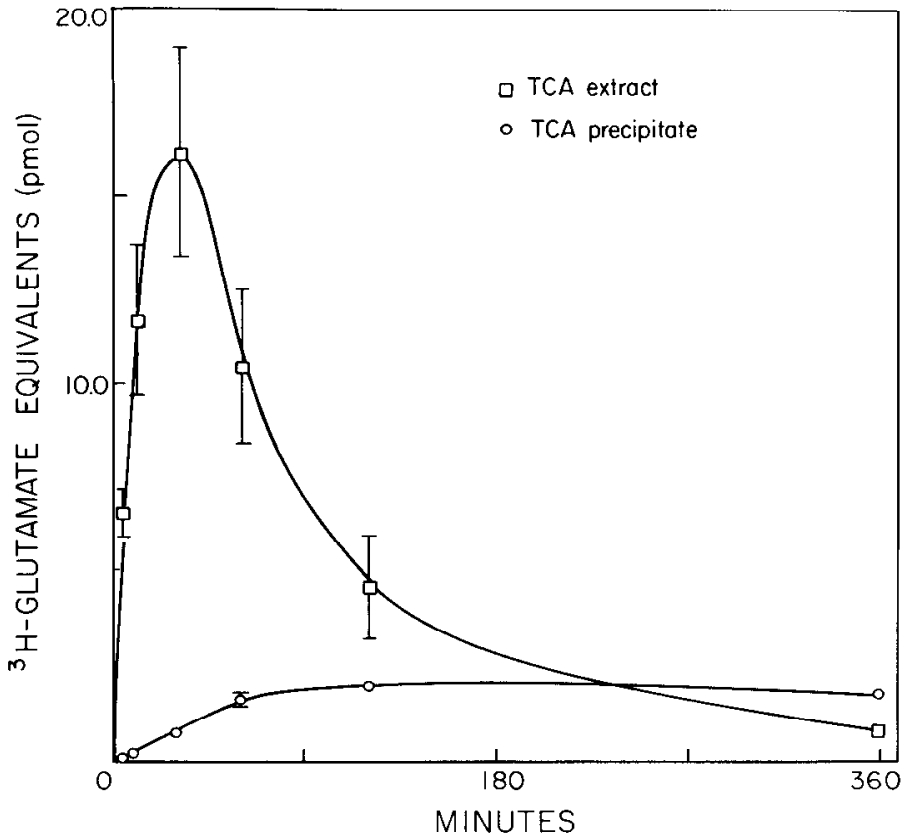

Figure 2. Time course of the ${ }^{3} \mathrm{H}$ accumulation and distribution from $\left.\mathrm{L}-{ }^{3} \mathrm{H}\right]$ glutamic acid between the trichloroacetic acid (TCA)-soluble and -insoluble cell fractions. Each point represents the mean ( \pm SEM) of triplicate determinations. Cells were rinsed and extracted for $24 \mathrm{hr}$ with $5 \%$ TCA after incubation with $1 \mu \mathrm{M} \mathrm{L}-\left[{ }^{3} \mathrm{H}\right]$ glutamate.

on uptake of $10 \mu \mathrm{M}$ glutamate. However, increasing the number of rinses from three to four reduced the variability in replicate determinations. Control wells without cells were incubated with $10 \mu \mathrm{M} \mathrm{L}-\left[{ }^{3} \mathrm{H}\right]$ glutamate, and no association of the label with the surface of the wells was detected.

Kinetic studies of L-glutamic acid influx were performed with substrate concentrations ranging from $1 \mu \mathrm{M}$ to $5 \mathrm{mM}$. These experiments revealed that total uptake was not saturable, and an Eadie-Hofstee plot of the data was nonlinear, a finding consistent with more than one component of uptake. A graphic method (Rosenthal, 1967) for resolving the curve from this plot into two components produced one line with a $K_{m}$ of $111 \mu \mathrm{M}$ and a $V_{\max }$ of $1.29 \mathrm{nmol} / \mathrm{min} / \mathrm{mg}$ of protein and a second component best described as nonsaturable (referred to as the low affinity component) (Waniewski and Martin, 1981). Since active transport of glutamate is a temperature-dependent process (Logan and Snyder, 1971; Roberts and Keen, 1974), initial velocity experiments were repeated at both $37^{\circ} \mathrm{C}$ and 0 to $4^{\circ} \mathrm{C}$ to identify the nature of the low affinity component. Additional substrate concentrations also were included up to $50 \mathrm{~mm}$ in an attempt to achieve saturation. The amount of $\mathrm{L}-\left[{ }^{3} \mathrm{H}\right]$ glutamate associated with the cells at 0 to $4^{\circ} \mathrm{C}$ continued to increase linearly with increasing substrate concentration (Fig. 3 ). The low affinity component at $37^{\circ} \mathrm{C}$ and the association at 0 to $4^{\circ} \mathrm{C}$ both appeared to be nonsaturable and of the same magnitude, suggesting that the same process was responsible for both. A satisfactory fit of the Michaelis-Menten equation to the data was obtained after the low affinity component was subtracted from total uptake. The fitted line and kinetic constants obtained by the method of Eisenthal and Cornish-Bowden (1974) and the reciprocals of the mean velocities are shown on a Lineweaver-Burke plot (Fig. 4). The $K_{m}$ and $V_{\max }$ values and their associated standard errors obtained for the saturable component by the method of Cleland (1967) were $123 \pm 12.7$ $\mu \mathrm{M}$ and $2.99 \pm 0.095 \mathrm{nmol} / \mathrm{min} / \mathrm{mg}$ of protein, respectively. Henceforth, we refer to this component as the high affinity component of L-glutamate transport.
The specificity of the high affinity L-glutamate transport system in LRM55 cells was examined by measuring the inhibitory potency of various glutamate analogues (Fig. 5). The most potent inhibitors (L-cysteine sulfinic acid, L-cysteic acid, and $\mathrm{L}$-aspartic acid) were required in at least a 27 -fold excess of $\mathrm{L}$ glutamate $(10 \mu \mathrm{M})$ to inhibit uptake by $50 \%$. To achieve conditions kinetically equivalent to those used by other investigators (Roberts and Watkins, 1975; Schousboe et al., 1977), Lcysteine sulfinic acid, L-cysteic acid, and L-aspartic acid were also tested as inhibitors of $\mathrm{L}$-glutamate uptake at a concentration close to its $K_{m}(100 \mu \mathrm{M})$. At the highest concentration of inhibitor tested ( $3.16 \mathrm{mM})$, L-glutamate uptake was inhibited only 10 to $25 \%$ by each of the three analogues. A few compounds appeared to facilitate glutamate uptake (points falling below $0 \%$, Fig. 5). The following glutamate analogues, amino acids, and inhibitors of GAD were also tested at $1 \mathrm{mM}$ and found to have no effect on high affinity $\mathrm{L}-\left[{ }^{3} \mathrm{H}\right]$ glutamate uptake by LRM55 cells: 1,2,4-benzenetricarboxylic acid; 2,6-pyridinedicarboxylic acid; $N$-acetyl-L-glutamic acid; glutamic acid diethylester; $N$-acetyl-D,L-aspartic acid; D- $\alpha$-aminoadipic acid; 2 amino-3-phosphonopropionic acid; 2-amino-4-phosphonobutyric acid; 2,4-diaminobutyric acid; $\alpha$-aminoisobutyric acid; 3,4dihydroxybenzoic acid; 3,4-dihydroxyphenylacetic acid; chelidonic acid; folic acid; gallic acid; $\alpha$-ketoglutaric acid; L-glutamine; asparagine; glycine; taurine.

Several metabolic inhibitors were tested to determine the dependence of high affinity glutamate transport on energy metabolism (Table I). In all cases LRM55 cells were exposed to the test substance for a $15-\mathrm{min}$ pre-incubation and during the influx period. With the exception of carbonylcyanide- $m$ chlorophenyl hydrazone (CCCP), none of the inhibitors of oxidative phosphorylation or electron transport was very effective in reducing $\mathrm{L}-\left[{ }^{3} \mathrm{H}\right]$ glutamate uptake. The inhibition by CCCP may be due to some secondary effects of this compound at the very high concentration used, especially since, 2,4-dinitrophenol, another uncoupler of oxidative phosphorylation, was almost without effect. The $\gamma$-glutamylnitroanilide, also found to be ineffective, was used to inhibit $\gamma$-glutamyl-transpeptidase, an enzyme capable of transporting glutamate (Orlowski and Meister, 1970).

The sodium dependence of high affinity glutamate transport was examined under conditions in which sodium was replaced with choline (Fig. 6). The initial velocity of influx was significantly reduced by total elimination of sodium but only to about $30 \%$ of control. The velocity of uptake in the absence of sodium was significantly different from uptake at 0 to $4^{\circ} \mathrm{C}(p<0.001$ by the Student's $t$ test). To determine whether uptake either in the presence or absence of sodium represents accumulation in an intracellular compartment or merely association with cell membranes, LRM55 cells were pre-incubated in gramicidin-S $(0.25 \mathrm{mM})$ for $5 \mathrm{~min}$ to make them leaky and, therefore, incapable of net uptake. Uptake, examined for $5 \mathrm{~min}$ after removing the gramicidin-S, was reduced to $16 \%$ of control, the level found both at 0 to $4^{\circ} \mathrm{C}$ and in the absence of sodium chloride (Table II). Ethanol $(0.5 \%)$, required to dissolve gramicidin-S, when also added to the control media, may have inhibited sodiumdependent uptake. This would explain the reduced contribution of sodium-dependent uptake $(22 \%)$ to the total uptake when compared to the $60 \%$ contribution in Figure 6 . The fact that a significant fraction of glutamate influx was maintained in the absence of sodium suggested that another transport mechanism was operating.

Because of the difference between the uptake in sodium-free and sodium chloride-free medium, the possibility of a $\mathrm{Cl}^{-}$ requirement was considered. Previous work in our laboratory (Wolpaw and Martin, 1984) indicated that LRM55 cells have very active chloride transport systems. To determine if $\mathrm{Cl}^{-}$ might be involved, its effect on high affinity glutamate uptake 


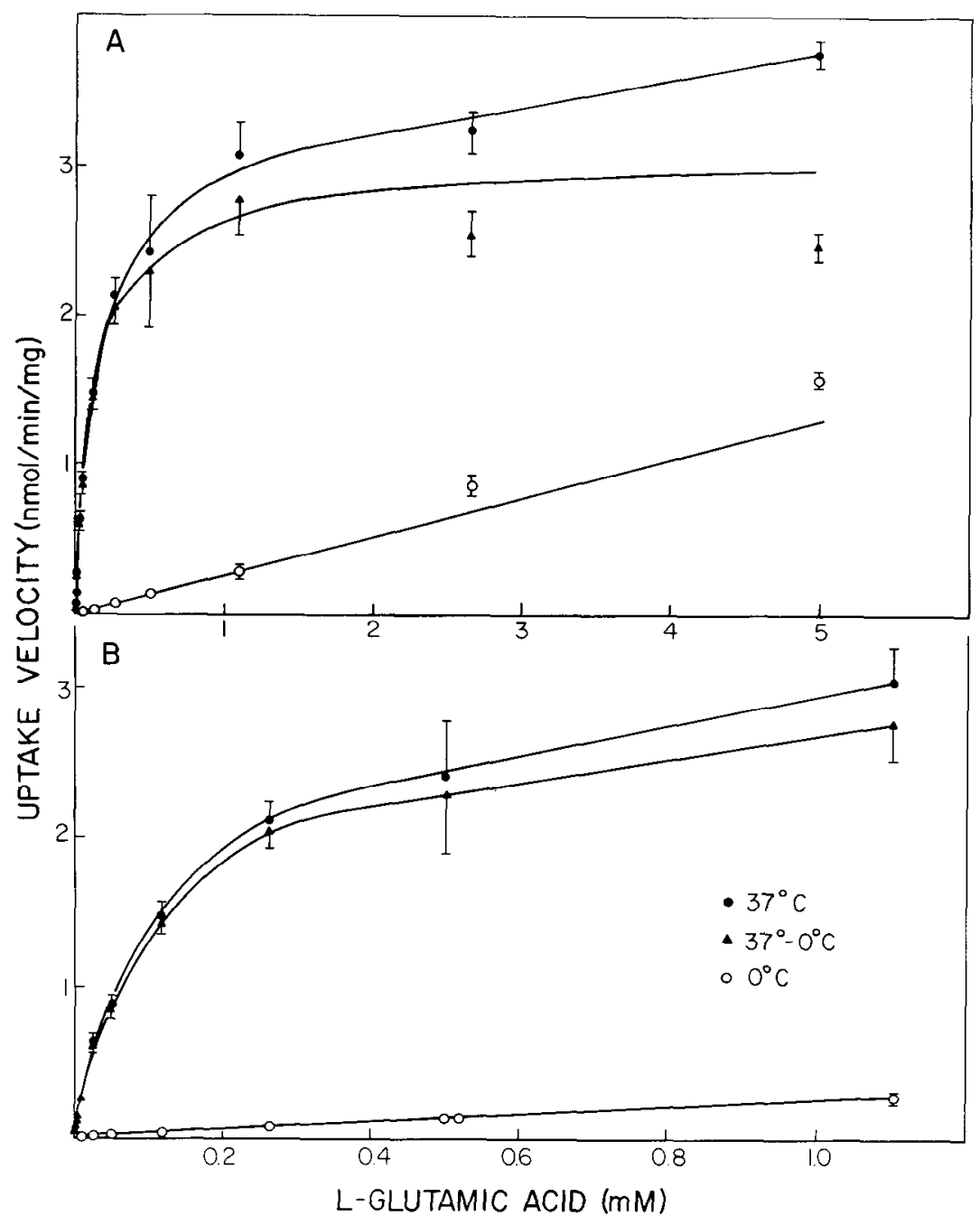

Figure 3. Substrate velocity curves for the initial velocity of glutamate influx at $37^{\circ} \mathrm{C}$ and 0 to $4^{\circ} \mathrm{C}$. $A$, High substrate concentrations. $B$, Substrate concentrations ranging from $1 \mu \mathrm{M}$ to $1 \mathrm{mM}$. Each point represents the mean ( $\pm \mathrm{SEM}$ ) of five determinations. The line through the 0 to $4^{\circ} \mathrm{C}$ points was fit by linear regression using the method of least squares for the velocities obtained at $1 \mu \mathrm{M}$ to $1.1 \mathrm{mM}$ substrate. This line was then used to correct the points obtained at $37^{\circ} \mathrm{C}$ for all substrate concentrations. $\Delta$, Differences between points on the $37^{\circ} \mathrm{C}$ and the 0 to $4^{\circ} \mathrm{C}$ lines.

was studied in both the presence and absence of sodium. The results (Fig. 7) indicate that uptake is strongly dependent on low concentrations of chloride but independent of chloride at levels greater than $5 \mathrm{~mm}$. In chloride-free medium uptake is sharply reduced in both the presence and absence of sodium. In another experiment uptake was reduced to the same degree when sodium was replaced with lithium or choline. Similarly, transport was reduced to the same degree when $\mathrm{Cl}^{-}$was replaced with the impermeant anions, isethionate or gluconate (Fig. 8). Replacement of both sodium and chloride ions with isosmotic sucrose produced an additive effect, reducing glutamate influx to the level obtained at 0 to $4^{\circ} \mathrm{C}$ in the presence of sodium chloride.

The effect of other medium components on glutamate transport was also examined. Elimination of potassium (Table III) or phosphate or lowering the $\mathrm{pH}$ by 1.5 units had no effect on the initial velocity of high affinity glutamate influx. However, elevating extracellular potassium to $26 \mathrm{~mm}$ accelerated the initial rate of transport of 1 and $10 \mu \mathrm{M} \mathrm{L}-\left[{ }^{3} \mathrm{H}\right]$ glutamate to 137 and $118 \%$ of control, respectively, but had no effect on low affinity uptake measured at $10 \mathrm{~mm}$ glutamate (Table III).

High affinity transport of glutamate into a cerebellar nerve cell line (Stallcup et al., 1979), cortical synaptosomes (Wheeler, 1979), and primary astrocytes (Drejer et al., 1982) has been reported to be tightly coupled to sodium transport. To test this property in LRM55 cells, the change in the intracellular ${ }^{22} \mathrm{Na}$ content during the initial influx of $\mathrm{L}-\left[{ }^{3} \mathrm{H}\right]$ glutamic acid was measured at several glutamate concentrations in both the presence and absence of ouabain ( $5 \mathrm{mM}$ ). Intracellular sodium was slightly elevated during the influx of 50 and $500 \mu \mathrm{M}$ glutamate but only in the absence of ouabain (Table IV). Ouabain increased intracellular sodium levels by $310 \%$ but reduced high affinity glutamate uptake (at 50 and $500 \mu \mathrm{M}$ ) by only 20 and $24 \%$, respectively. Low affinity uptake (at $5 \mathrm{~mm}$ ) was not affected.

The stimulating effect of elevated potassium on glutamate uptake suggested that this cation might be co-transported with glutamate. However, glutamate at 25, 33, 50, 100, 500, 1000, and $5000 \mu \mathrm{M}$ had no effect on either the influx or efflux of ${ }^{42} \mathrm{~K}$.

The effect of glutamate on ${ }^{36} \mathrm{Cl}^{-}$uptake was also examined. Addition of $5 \mathrm{~mm}$ glutamate to the incubation medium had no effect on the initial velocity of ${ }^{36} \mathrm{Cl}^{-}$uptake during a 2 -min incubation period.

The chloride dependence of glutamate influx suggested that 
pharmacological manipulation of chloride transport might alter glutamate uptake, so several drugs known to affect various mechanisms of $\mathrm{Cl}^{-}$movement were examined (Table V). Picrotoxin, a blocker of GABA-activated neuronal chloride conductance (Ticku et al. 1978), had little effect. Furosemide and ethacrynic acid, inhibitors of active chloride transport in the thick ascending limb of Henle's loop (Nechay, 1977), differed in their effects; fuorsemide reduced uptake only slightly, but ethacrynic acid significantly inhibited glutamate uptake. SITS

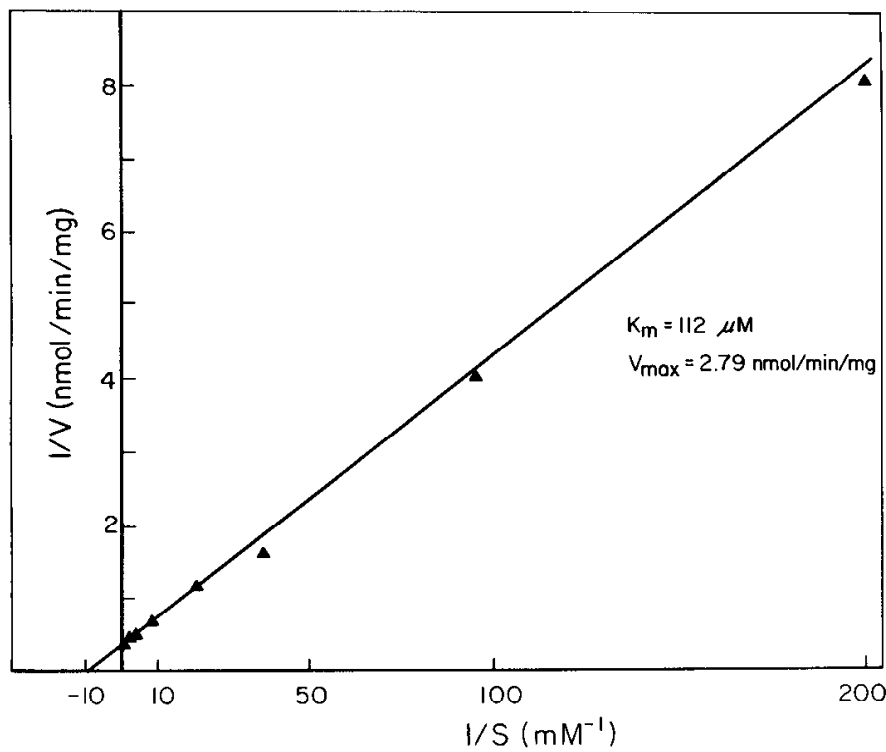

Figure 4. A Lineweaver-Burke plot of the velocities obtained by subtracting points on the 0 to $4^{\circ} \mathrm{C}$ line from those on the $37^{\circ} \mathrm{C}$ line for substrate concentrations from $5 \mu \mathrm{M}$ to $1 \mathrm{mM}$. The line through the points and the kinetic constants were derived by the method of Eisenthal and Cornish-Bowden (1974). The velocities obtained at 1 to $4 \mu \mathrm{M}$ substrate were also used in this analysis but are not shown. and DIDS, which are inhibitors of anion exchange in red blood cells (Cabantchik et al., 1978), and LRM55 cells (Wolpaw and Martin, 1984) were the most effective inhibitors of glutamate influx of the substances in this group.

Studies indicating the presence of neurotransmitter receptors on astrocytes (Henn and Henke, 1978; Harden and McCarthy, 1982; Hosli and Hosli, 1982) prompted an examination of several neuropharmacological agents for their effects on glutamate influx. Only minor changes were observed at the high concentrations tested (Table V).

\section{TABLE I}

Effects of metabolic inhibitors on the initial velocity of $L-\left[{ }^{3} H\right]$ glutamate influx

LRM55 glioma cells were pre-incubated for $15 \mathrm{~min}$ with inhibitor. Influx during a 5-min incubation with $20 \mu \mathrm{M} \mathrm{L}$ - $\left[{ }^{3} \mathrm{H}\right]$ glutamate was determined, with the mean $\pm \mathrm{SD}$ velocity of influx expressed as a percentage of the control velocity. Uptake in lead acetate- and acetazolamide-treated cells was compared to controls in separate experiments, and the results were statistically analyzed by the Student's $t$ test. The remaining substances were tested against the same control group in a single experiment, and the results were compared by oneway analysis of variance followed by a two-tailed Dunnett's test. All compounds were used at $1 \mathrm{~mm}$, except ouabain $(5 \mathrm{mM})$.

\begin{tabular}{lc}
\hline \multicolumn{1}{c}{ Test Substance $(n)$} & $\begin{array}{c}\text { Percentage of } \\
\text { Control Influx }\end{array}$ \\
\hline Potassium cyanide (3) & $118 \pm 12$ \\
Acetazolamide (4) & $90.4 \pm 11.7$ \\
2,4-Dinitrophenol (3) & $90.3 \pm 4.1$ \\
Azaserine (3) & $85.9 \pm 10.4$ \\
L- $\gamma$-Glutamylnitroanilide (3) & $82.3 \pm 18.4$ \\
Lead acetate (5) & $77.3 \pm 3.6^{a}$ \\
Ouabain octahydrate (3) & $59.9 \pm 8.0^{b}$ \\
Carbonyl cyanide- $m$-chlorophenyl hydrazone (3) & $25.7 \pm 1.7^{a}$ \\
\hline
\end{tabular}

${ }^{a} p<0.001$, significantly different from control influx. ${ }^{b} \mathrm{p}<0.01$.

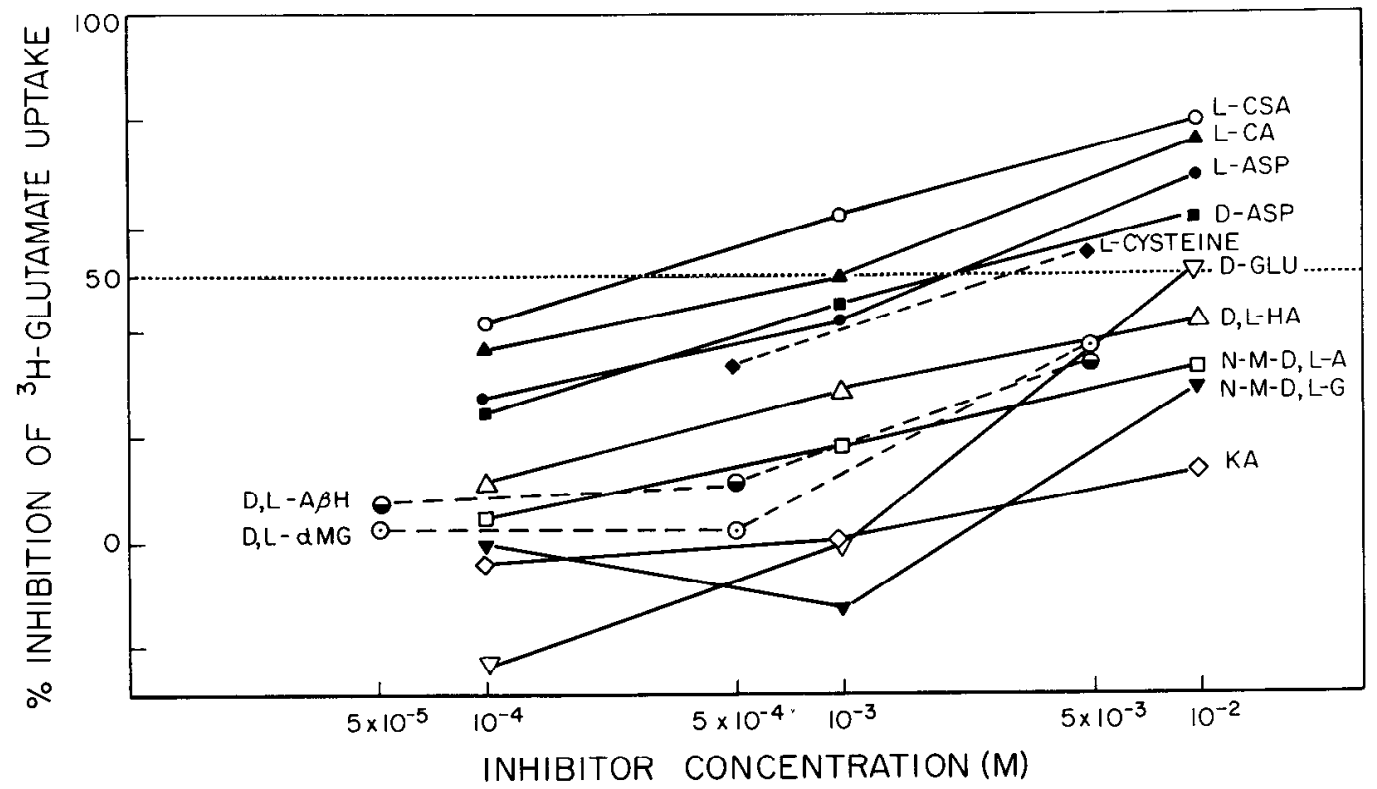

Figure 5. Dose-response curves for glutamate analogues inhibiting high affinity L- $\left[{ }^{3} \mathrm{H}\right]$ glutamate uptake. Cells were incubated simultaneously with $10 \mu \mathrm{M}$ L-glutamate and the indicated concentration of inhibitor. Complete names for abbreviations are L-cysteine sulfinic acid $(L-C S A)$, L-cysteic acid $(L-C A)$, L-aspartic acid $(L-A S P), \mathrm{D}$-aspartic acid $(D-A S P)$, D-glutamic acid $(D-G L U), \mathrm{D}, \mathrm{L}-$ homocysteic acid $(D, L-H A), \mathrm{D}, \mathrm{L}-\alpha-$ methyl glutamate $(D, L-\alpha M G), \mathrm{D}, \mathrm{L}$-aspartate- $\beta$-hydroxamate $(\mathrm{D}, \mathrm{L}-A \beta H), N$-methyl-D,L-aspartate $(N-M-D$, $L$-A), $N$-methyl-D,L-glutamate (N-M-D,L-G), and kainic acid ( $K A)$. Quisqualic acid was also tested but only at $1 \mathrm{mM}$, producing $30 \%$ inhibition. Each point represents the mean of three determinations expressed as 100 minus the percentage of control uptake. The SD was $<10 \%$ of the mean velocity in all cases. 


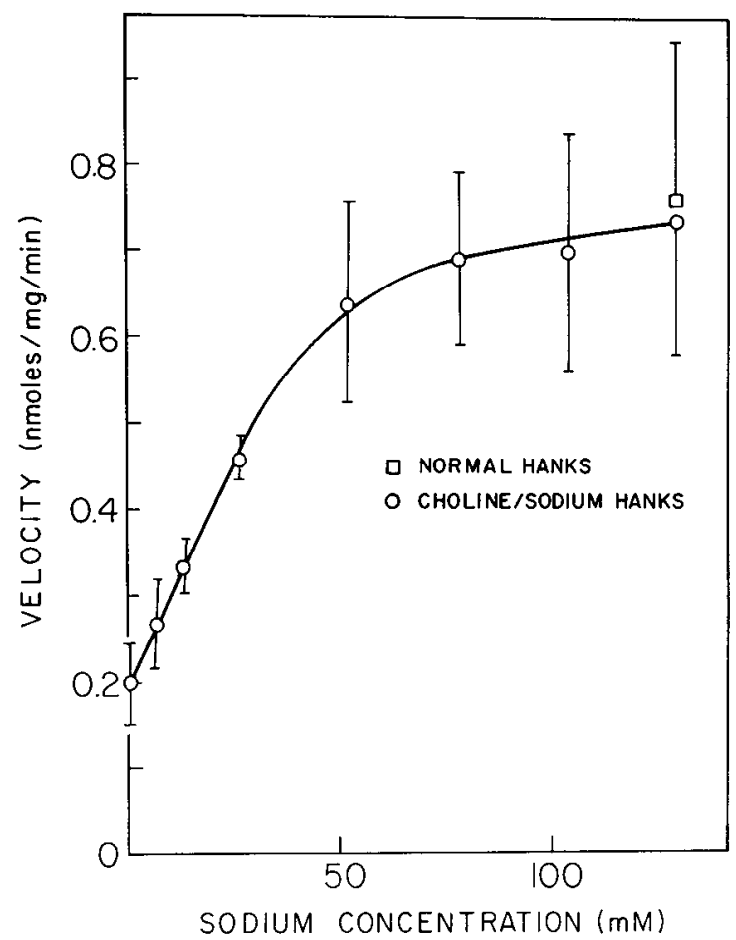

Figure 6. The sodium dependence of $\mathbf{L}-\left[{ }^{3} \mathrm{H}\right]$ glutamate influx. Sodium was substituted with choline during the 30 -min pre-incubation period and the 5 -min incubation with $80 \mu \mathrm{M} \mathrm{L}-\left[{ }^{3} \mathrm{H}\right]$ glutamate. The velocities of uptake have been corrected for uptake at 0 to $4^{\circ} \mathrm{C}$. The points represent the mean ( $\pm \mathrm{SD}$ ) velocities for four determinations at each sodium concentration. The velocity was significantly reduced only at sodium concentrations $<50 \mathrm{~mm}$ ( $p<0.01$ by Dunnett's test).

TABLE II

Effect of gramicidin-S on sodium chloride-dependent and sodiumindependent $L-\left[{ }^{3} \mathrm{H}\right]$ glutamate uptake

Cells were pre-incubated with or without $0.25 \mathrm{~mm}$ gramicidin-S for $5 \mathrm{~min}$. This medium was removed and replaced with medium containing $80 \mu \mathrm{M} \mathrm{L}-\left[{ }^{3} \mathrm{H}\right]$ glutamate for uptake ( $n=5$ for each group).

\begin{tabular}{cc}
\hline Medium Contents & Uptake Velocity \\
\hline & pmol/min/mg of protein \\
Normal sodium chloride & $388 \pm 38$ \\
+ gramicidin-S & $63.9 \pm 5.9^{a}$ \\
No sodium & $302 \pm 34^{a}$ \\
$\quad+$ gramicidin-S & $56.0 \pm 8.1^{b}$ \\
No sodium chloride & $68.3 \pm 4.8$ \\
$\quad+$ gramicidin-S & $80.1 \pm 8.8$ \\
Normal sodium chloride & \\
(0 to $\left.4^{\circ} \mathrm{C}\right)$ & $68.2 \pm 24.8^{b}$ \\
\hline
\end{tabular}

${ }^{a}$ Significantly different from cells incubated in normal sodium chloride-containing medium, $p<0.001$ by Newman-Keuls multiple range test.

${ }^{b}$ Significantly different from cells incubated in sodium-free medium, $p<0.001$ by Newman-Keuls multiple range test.

\section{Discussion}

The time course and subcellular distribution studies indicate that $\left[{ }^{3} \mathrm{H}\right]$ glutamate is rapidly and extensively metabolized and/ or released after being taken up. The tritium label is partially incorporated in cell proteins and otherwise lost from the cell interior. This meant that by following the tritium label alone it was impossible to determine whether transport represented net uptake or exchange of intracellular for extracellular glutamate. Therefore, the studies presented here have been focused

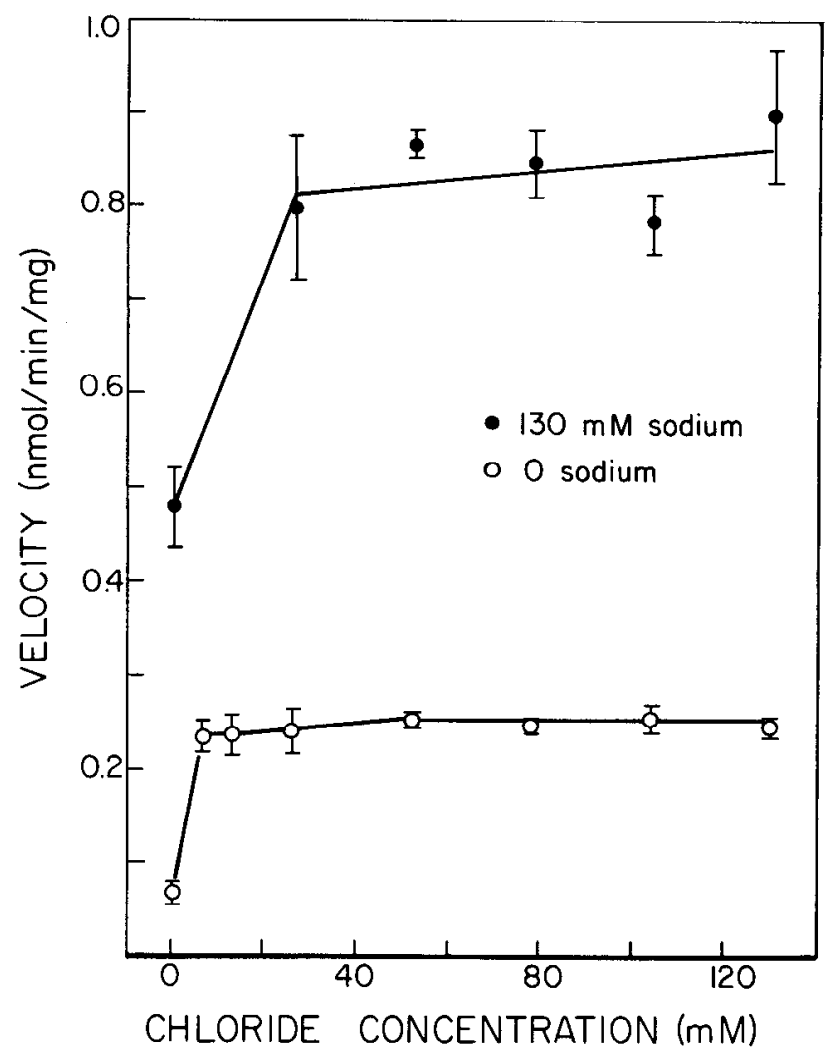

Figure 7. The chloride dependence of glutamate influx in the presence and absence of sodium. Chloride was replaced with isethionate in the normal sodium medium $(130 \mathrm{~mm})$. Choline chloride was replaced with sucrose in the sodium-free medium. In normal and sodium-free medium, uptake was significantly reduced only when chloride was absent $(p<0.01$, Dunnett's test). Uptake in normal chloride- and sodium-free medium was significantly less than in normal sodium chloride-containing medium ( $p<0.01$, Dunnett's test).

principally on matters that can be addressed by initial velocity experiments, such as determining the number of kinetic components, their substrate specificity, ion dependencies, and susceptibility to inhibitors.

The uptake of glutamate by LRM55 cells appears to comprise at least three components, as revealed by kinetic, temperature, and ion dependence experiments. The apparent "low affinity" uptake was not saturable by glutamate, was insensitive to temperature, and was sodium chloride-independent. This process could account for most of the uptake observed at concentrations $>1 \mathrm{mM}$. High affinity glutamate uptake, which was extremely substrate-specific and temperature-sensitive, could be divided into two components based on ionic dependence. Approximately $65 \%$ of high affinity uptake was sodium-dependent, and the remainder was chloride-dependent. It is not clear whether the sodium- and chloride-dependent components represent partial ion dependencies of a single transport system or two independent transport systems. Together, low affinity uptake and the two components of high affinity uptake account for the total influx of $\left.\mathrm{L}-{ }^{3} \mathrm{H}\right]$ glutamate by these cells.

Other investigators have reported two saturable kinetic components of glutamate uptake in glial cell preparations with $K_{m}$ values ranging from 12 to $66 \mu \mathrm{M}$ for high affinity uptake and 0.13 to $1.3 \mathrm{~mm}$ for low affinity uptake (Faivre-Bauman et al., 1974; Henn et al., 1974; Roberts and Keen, 1974). Campluell and Shank (1978) reported a third component having a $K_{m}$ of $3 \mu \mathrm{M}$ in glial-enriched preparations from mouse cerebellum. Our results agree more closely with those of Balcar et al. (1977), Schousboe et al. (1977), and Hertz et al. (1978), who have 


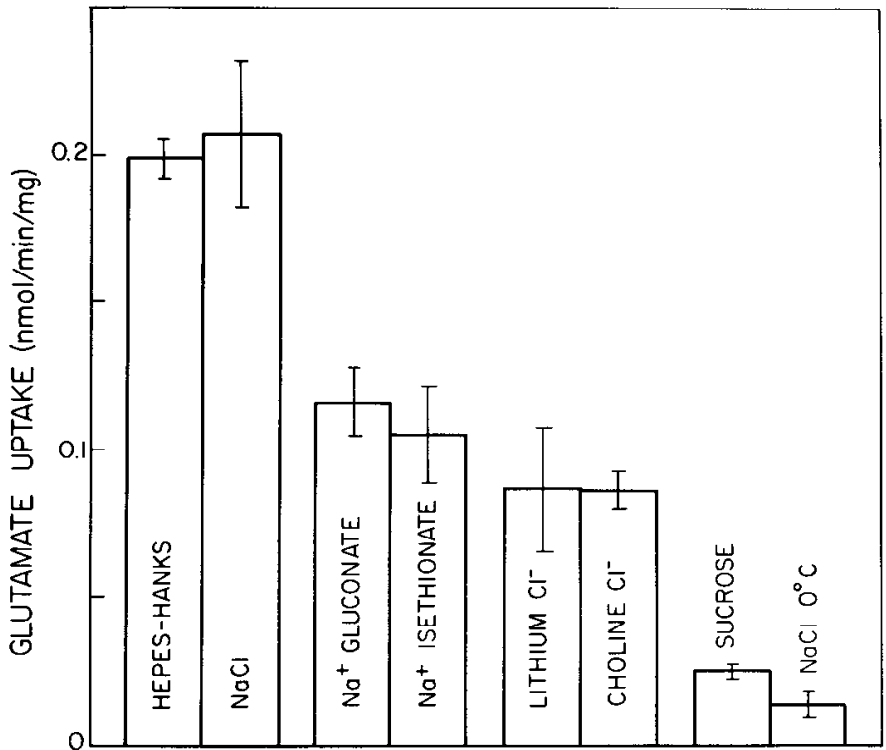

\section{IONIC SUBSTITUTED MEDIA}

Figure 8. The sodium and chloride dependence of high affinity glutamate uptake using several ionic substitutes. Cells were rinsed and pre-incubated with the appropriate medium prior to uptake of $80 \mu \mathrm{M}$ $\mathrm{L}-\left[{ }^{3} \mathrm{H}\right]$ glutamate. Uptake in both the sodium- and chloride-substituted media was significantly different from the control uptake. Uptake in medium in which sucrose was substituted for sodium chloride or in medium at 0 to $4^{\circ} \mathrm{C}$ was significantly different from uptake in the sodium-free or the chloride-free media $(p<0.001$, Newman-Keuls multiple range test), but these were not significantly different from each other. Histograms represent the mean $( \pm \mathrm{SD})$ of five determinations.

\section{TABLE III}

Effect of potassium ion on the initial velocity of $L-\left[{ }^{3} H\right]$ glutamate influx

LRM55 cells were thoroughly rinsed and pre-incubated for $30 \mathrm{~min}$ in media containing the indicated concentration of potassium. $\mathrm{L}-\left[{ }^{3} \mathrm{H}\right]$ Glutamate at three different concentrations was added in the same medium, and cell contents were measured after $5 \mathrm{~min}$. Values represent the mean $\pm \mathrm{SD}$ of three determinations.

\begin{tabular}{|c|c|c|c|}
\hline \multirow{2}{*}{ Potassium in Medium } & \multicolumn{3}{|c|}{$\begin{array}{c}\text { Uplake Velocity al } \\
\text { L- }\left[{ }^{3} \mathrm{H}\right] \text { Glutamate Concentration of }\end{array}$} \\
\hline & $1 \mu \mathrm{M}$ & $10 \mu \mathrm{M}$ & $10 \mathrm{mM}$ \\
\hline$m M$ & \multicolumn{3}{|c|}{$\mathrm{pmol} / \mathrm{min} / \mathrm{mg}$ of protein } \\
\hline 0 & $24.8 \pm 1.9$ & $233 \pm 12$ & $27,600 \pm 3,020$ \\
\hline 4.6 (control) & $23.6 \pm 1.1$ & $237 \pm 9$ & $29,600 \pm 2,360$ \\
\hline 26 & $32.3 \pm 0.4^{a}$ & $280 \pm 6^{a}$ & $26,000 \pm 3,350$ \\
\hline
\end{tabular}

${ }^{a} p<0.01$, significantly different from control by Dunnett's twotailed test.

reported a single high affinity component and a nonsaturable low affinity component in cultured glial cells. The reported $K_{m}$ values for their cultured astrocytes are quite variable, ranging from 15 to $220 \mu \mathrm{M}$. The $K_{m}$ value for the high affinity system in LRM55 cells $(123 \mu \mathrm{M})$ is in this range, although toward the high end. The differences in $K_{m}$ for different cultures of glia could be due to small differences in experimental conditions or to the origin of the glial cells. Schousboe and Divac (1979) and Drejer et al. (1982) have reported regional brain differences in the velocity of glutamate uptake by primary cultures of astrocytes. All other kinetic studies have used glia from peripheral tissues or cerebral cortex, while LRM55 glioma cells are derived from spinal cord. The $V_{\max }$ for high affinity uptake by LRM55
TABLE IV

Sodium and L-glutamate transport by LRM55 cells

I.RM55 cells were pre-incubated for $30 \mathrm{~min}$ with ${ }^{22} \mathrm{Na}$-containing medium in the presence or absence of ouabain octahydrate. $\mathrm{L}-\left[{ }^{3} \mathrm{H}\right]$ Glutamate was then added directly to the pre-incubation medium at the indicated final concentration, and the ${ }^{22} \mathrm{Na}$ and $\mathrm{L}-\left[{ }^{3} \mathrm{H}\right]$ glutamate contents were measured after a 5 -min incubation period. For each treatment group, $n=5$. Data represent the mean $\pm \mathrm{SD}$ sodium content and $\left[{ }^{3} \mathrm{H}\right]$ glutamate accumulated for each group. Comparison of the sodium content for the combined ouabain-versus non-ouabain-treated groups by the Student's $t$ test revealed a significant difference $(p<$ $0.001)$.

\begin{tabular}{lccc}
\hline $\begin{array}{c}\text { Pre-incubation } \\
\text { Additions }\end{array}$ & $\begin{array}{c}\text { L-Glutamate } \\
\text { Concentration }\end{array}$ & $\begin{array}{c}\text { I- }\left[{ }^{3} \mathrm{H}\right] \text { Clutamic Acid } \\
\text { Accumulated }\end{array}$ & ${ }^{22} \mathrm{Na}$ Content \\
\hline \multirow{3}{*}{ None } & $\mu M$ & & nmol/mg of protein \\
& 0 & & $75.1 \pm 12.2$ \\
& 50 & $1.23 \pm 0.18$ & $95.8 \pm 10.7^{b}$ \\
& 500 & $3.83 \pm 0.17$ & $99.0 \pm 24.3^{b}$ \\
Ouabain (5 mM) & 5000 & $19.5 \pm 2.0$ & $70.2 \pm 9.0$ \\
& 0 & & $308 \pm 20$ \\
& 50 & $0.981 \pm 0.103^{a}$ & $278 \pm 51$ \\
& 500 & $2.92 \pm 0.81^{a}$ & $290 \pm 20$ \\
& 5000 & $19.8 \pm 2.4$ & $273 \pm 21$ \\
\hline
\end{tabular}

${ }^{a} p<0.05$ compared to control $\mathrm{L}-\left[{ }^{3} \mathrm{H}\right]$ glutamate uptake (absence of ouabain) at the same substrate concentration by the Student's $t$ test.

${ }^{b} p<0.05$ compared to control ${ }^{22} \mathrm{Na}$ content in the absence of glutamate by Dunnett's two-tailed test.

cells is very similar to those reported for brain slices, homogenates, and cultured glia (see Schousboe, 1981, for review).

Sodium dependency has been generally accepted as a cardinal property of high affinity amino acid transport, but a significant proportion $(35 \%)$ of glutamate influx in LRM55 cells was sodium-independent. When sodium-independent uptake was observed in other systems, it was generally attributed to the low affinity transport system. In LRM55 cells this sodiumindependent uptake was found to be chloride-dependent, and because of the close fit of sodium plus chloride-dependent transport to a single saturation function it is not possible to attribute it to low affinity uptake. In an autoradiographic study Hosli and Hosli (1976) found evidence of sodium-independent uptake by spinal cord slices. Since the LRM55 glioma cells are of spinal origin, it is possible that sodium independence is a property characteristic of this tissue. Chloride dependence has been described for glutamate uptake by synaptosomes (Kuhar and Zarbin, 1978), but this is the first report of chloride dependence in a glial cell type. The failure of glutamate to affect chloride influx in LRM55 cells indicates that neither of the major chloride porters is responsible for high or low affinity glutamate transport, a conclusion also supported by the differential pharmacological susceptibilities of glutamate and chloride influx. The possibility that the high affinity glutamate transport system might co-transport or exchange glutamate and chloride is not ruled out by these data since the chloride flux carried out hy the glutamate porter would be a small fraction of the total flux and, thus, difficult to quantify. Other less direct roles for chloride are also possible; chloride may be required for activation of some other transporter. For example, a SITS-inhibitable, chloride-activated $\mathrm{Mg}^{2+}$ ATPase has been found which supports catecholamine transport in chromaffin granules (Ramu et al., 1981). The LRM55 glutamate transporter bears a striking resemblance to the high affinity transport of glycine by human erythrocytes, which has a sodiumindependent, chloride-dependent component inhibitable by SITS (Ellory et al., 1981).

Of the pharmacological agents tested, those compounds that interfere with chloride exchange or transport (SITS, DIDS, 
TABLE V

Effect of drugs on glutamate influx

Cells were pre-incubated for $15 \mathrm{~min}$ with each drug prior to the 5 -min influx incubation period. Bicuculline, isoniazid, strychnine, and picrotoxin were all tested in the same experiment versus the same two control groups $(n=5)$, and the results were analyzed by one-way analysis of variance followed by a two-tailed Dunnett's test. All other drugs were tested against a control group in separate experiments $(n=3)$, and the significance of the mean differences was determined by $t$ tests. All drugs were tested at $1 \mathrm{mM}$ with the exception of diazepam (100 $\mu \mathrm{M}$ ). Glutamate was used at a concentration of $80 \mu \mathrm{M}$ when testing diazepam, ethacrynic acid, baclofen, isoproterenol, picrotoxin, and furosemide. The remaining drugs were tested with $20 \mu \mathrm{M}$ substrate.

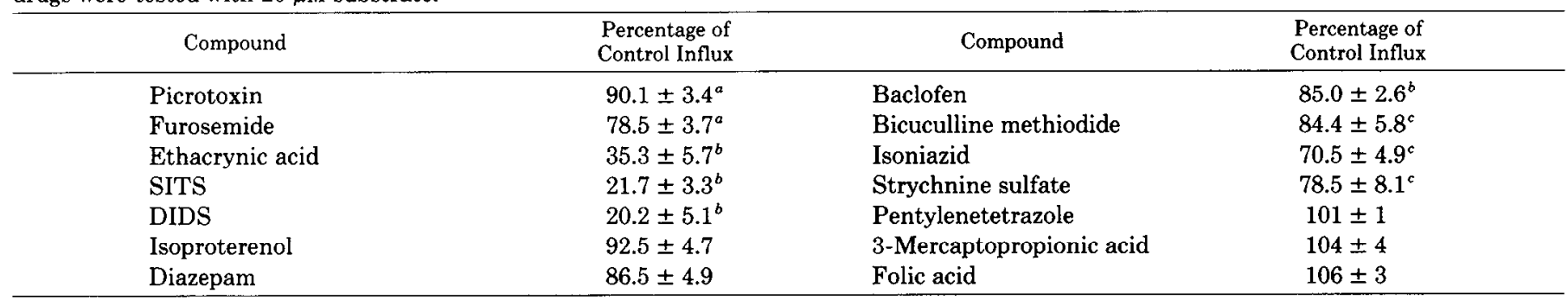

$$
\begin{aligned}
& { }^{a} p<0.05 . \\
& { }^{b} p<0.001 . \\
& { }^{c} p<0.01
\end{aligned}
$$

and ethacrynic acid) were the most effective inhibitors of glutamate transport by LRM55 cells. Although these effects are consistent with the chloride dependence of glutamate transport, the chloride requirement does not appear to be related to anion movement in LRM55 cells. First, these drugs only partially inhibit chloride movement in these cells, and furosemide, which is a more effective inhibitor of chloride movement (Wolpaw and Martin, 1984), is a poor inhibitor of glutamate transport. Second, the degree of inhibition by SITS, DIDS, and ethacrynic acid is much greater than that produced by chloride removal.

We have demonstrated that SITS inhibits glutamate influx in astrocytes derived from cerebral cortex in the same manner as in LRM55 cells and that SITS inhibition is selective for glia over neurons (Waniewski and Martin, 1983). Ethacrynic acid and DIDS had no such glia-specific action (R. A. Waniewski and D. L. Martin, unpublished data).

The exact role of sodium in glutamate transport is unclear. The small elevation in intracellular sodium during transport of low concentrations of glutamate is consistent with a sodium co-transport mechanism. Sodium flux is at least 30 times faster than glutamate transport, so the glutamate-dependent increment in sodium content would be expected to be difficult to detect; in fact, no estimate of the stoichiometry of transport could be made, because the standard error in the sodium measurements approached the size of the glutamate-dependent increment in sodium content. In contrast, the effect of ouabain was not totally consistent with a sodium co-transport mechanism. Ouabain increased internal sodium more than 4-fold (to about $134 \mathrm{mM}$, based on previous measurements of cell volume; Martin and Shain, 1979) but inhibited glutamate influx by only 20 to $24 \%$. This result could be observed with a sodium cotransport system if there were a high proportion of homoexchange of external labeled glutamate with internal glutamate. Indeed, the lack of ouabain and potassium effects at high glutamate concentrations supports the hypothesis that the low affinity component is independent of sodium and different from the high affinity components.

The observation of sodium-independent, chloride-dependent high affinity influx is relevant to the interpretation of glutamate receptor binding studies. It is generally assumed that omitting sodium ion from incubation media for binding studies will eliminate uptake. However, our results suggest that uptake by glia could contribute significantly to binding measurements conducted in chloride-containing medium with intact cells.

The stimulating effect of elevated potassium found in this study has also been reported for rat brain synaptosomes (Kanner and Sharon, 1978) and primary astrocyte cultures (Schousboe et al., 1977), although Nicklas and Browning (1983) recently reported that elevated potassium ion $(30 \mathrm{~mm})$ inhibits glutamate uptake by $\mathrm{C} 6$ glioma cells. The methodological differences between the latter results and ours were minor, and the differences in the results may be due to cell lineage. Facilitation of glial influx would provide an efficient physiological means for removing extracellular glutamate during periods of excessive neuronal activity when extracellular potassium levels would be elevated.

The glutamate transport system in LRM55 cells has much greater substrate specificity than previously described for brain homogenates (Logan and Snyder, 1972), synaptosomes (Roberts and Watkins, 1975) or other glial preparations (Balcar et al., 1977; Drejer et al., 1982). Even the straight-chain acidic amino acids, which were the best inhibitors, were required in great excess to inhibit glutamate uptake effectively in LRM55 cells. Several reports have suggested that the L-glutamate transporter in glial preparations can transport L-aspartate equally as well (Roberts and Watkins, 1975; Balcar et al., 1977; Schousboe et al., 1977). 'The large excess of L-aspartate required for inhibition of glutamate uptake by LRM55 cells indicates that aspartate is not a good substrate for the glutamate transporter in these cells. Other analogues, which were either potent displacers of glutamate in binding studies or inhibitors of glutamate decarboxylase, were totally ineffective as inhibitors of uptake.

The LRM55 glioma cell line has provided a model for examining the properties of glial glutamate influx. These cells were found to possess properties similar to those described for other glial preparations, particularly the mouse brain astrocytes in culture studied by Schousboe et al. (1977). The increased velocity of high affinity uptake found in LRM55 cells relative to that in spinal roots (Roberts and Keen, 1974) and synaptic vesicles (Lähdesmäki et al., 1977) and the similarity of this rate to that found in brain slices (Balcar and Johnston, 1972) and homogenates (Logan and Snyder, 1972) and cultured astrocytes (Balcar and Hauser, 1978) demonstrates that these cells transport glutamate very much like normal astrocytes. The lack of effective inhibition of uptake with inhibitors of oxidative phosphorylation has also been observed in other studies with cultured cells. This could be due to the high glycolytic activity of cells in culture. The differences observed in substrate specificity, and ionic dependency for the LRM55 cells may be due to minor differences in methodology or to regional differences in 
the origin of these cells. The spinal cord has been reported to have glutamate transport properties different from those of the cerebrum (Logan and Snyder, 1972; Hosli and Hosli, 1976). It is not unreasonable to suggest that the glia from the spinal cord also differ from cerebral glia. However, the possibility that the observed nuances of glutamate influx in LRM55 cells are a peculiarity of this transformed cell line cannot be excluded.

\section{References}

Balazs, R., A. J. Patel, and D. Richter (1973) Metabolic compartments in the brain: Their properties and relation to morphological structures. In Metabolic Compartmentation in the Brain, R. Balazs and $\mathbf{J}$. E. Cremer, eds., pp 167-184, Macmillan, London.

Balcar, V. J., and K. L. Hauser (1978) Transport of $\left[{ }^{3} \mathrm{H}\right] \mathrm{L}$-glutamate and $\left[{ }^{3} \mathrm{H}\right] \mathrm{L}$-glutamine by dissociated glial and neuronal cells in primary culture. Proc. Eur. Soc. Neurochem. 1: 498.

Balcar, V. J., and G. A. K. Johnston (1972) The structural specificity of the high affinity uptake of L-glutamate and L-aspartate by rat brain slices. J. Neurochem. 19: 2657-2666.

Balcar, V. J., J. Borg, and P. Mandel (1977) High affinity uptake of Lglutamate and L-aspartate by glial cells. J. Neurochem. 28: 87-93.

Bradford, H. F., H. K. Ward, and A. J. Thomas (1978) Glutamine-a major substrate for nerve endings. J. Neurochem. 30: 1453-1459.

Cabantchik, Z. I., P. A. Knauf, and A. Rothstein (1978) The anion transport system of the red blood cell. The role of membrane protein evaluated by the use of "probes." Biochim. Biophys. Acta 515: 239302.

Campbell, G. L., and R. P. Shank (1978) Glutamic acid uptake by cerebellar granule and glial enriched populations. Brain Res. 153: 618-622.

Cleland, W. W. (1967) Statistical analysis of enzyme kinetic data. Adv. Enzymol. 29: 1-32.

Currie, D. N., and J. S. Kelly (1981) Glial versus neuronal uptake of glutamate. J. Exp. Biol. 95: 181-193.

Drejer, J., O. M. Larsson, and A. Schousboe (1982) Characterization of L-glutamate uptake into and release from astrocytes and neurons cultured from different brain regions. Exp. Brain Res. 47: 259-269.

Eisenthal, R., and A. Cornish-Bowden (1974) The direct linear plota new graphical procedure for estimating enzyme kinetic parameters. Biochem. J. 139: 715-720.

Ellory, J. C., S. E. M. Jones, and J. D. Young (1981) Glycine transport in human erythrocytes. J. Physiol. (Lond.) 320: 403-422.

Faivre-Bauman, A., J. Rossier, and P. Benda (1974) Glutamate accumulation by a clone of glial cells. Brain Res. 76: 371-375.

Gordon, R. D., and R. Balazs (1983) Characterization of separated cell types from the developing rat cerebellum: Transport of glutamate and aspartate by preparations enriched in Purkinje cells, granule neurons, and astrocytes. J. Neurochem. 40: 1090-1099.

Harden, T. K., and K. D. McCarthy (1982) Identification of the beta adrenergic receptor subtype on astroglia purified from rat brain. J. Pharmacol. Exp. Ther. 222: 600-605.

Henn, F. A., and A. Hamberger (1971) Glial cell function: Uptake of transmitter substances. Proc. Natl. Acad. Sci. U. S. A. 68: 26862690.

Henn, F. A., and D. J. Henke (1978) Cellular localization of $\left[{ }^{3} \mathrm{H}\right]$ diazepam receptors. Neuropharmacology 17: 985-988.

Henn, F. A., M. N. Goldstein, and A. Hamberger (1974) Uptake of the neurotransmitter candidate glutamate by glia. Nature (Lond.) 249 : $663-664$.

Hertz, L., A. Schousboe, N. Boechler, S. Mukerji, and S. Fedoroff (1978) Kinetic characteristics of the glutamate uptake into normal astrocytes in cultures. Neurochem. Res. 3: 1-14.

Hosli, E., and L. Hosli (1976) Uptake of L-glutamate and L-aspartate in neurones and glial cells of cultured human and rat spinal cord. Experientia 32: 219-222.

Hosli, E., and L. Hosli (1982) Evidence for the existence of $\alpha$ - and $\beta$ adrenoceptors on neurones and glial cells of cultured rat central nervous system-an autoradiographic study. Neuroscience 7: 28732881.

Kanner, B. I., and I. Sharon (1978) Active transport of L-glutamate by membrane vesicles isolated from rat brain. Biochemistry 17: 39493953.

Kuhar, M. J., and M. A. Zarbin (1978) Synaptosomal transport: A chloride dependence for choline, GABA, glycine and several other compounds. J. Neurochem. 31: 251-256.
Lähdesmäki, P., A. Karppinen, H. Saarni, and R. Winter (1977) Amino acids in the synaptic vesicle fraction from calf brain: Content, uptake and metabolism. Brain Res. 138: 295-308.

Logan, W. J., and S. H. Snyder (1971) Unique high affinity uptake systems for glycine, glutamic and aspartic acids in central nervous tissue of the rat. Nature (Lond.) 234: 297-299.

Logan, W. J., and S. H. Snyder (1972) High affinity uptake system for glycine, glutamic acid and aspartic acid in synaptosomes of rat central nervous tissues. Brain Res. 42: 413-431.

Lowry, O. H., N. J. Rosebrough, A. L. Farr, and R. J. Randall (1951) Protein measurement with the Folin phenol reagent. J. Biol. Chem. 193: 265-275.

Martin, D. L., and W. Shain (1979) High affinity transport of taurine and $\beta$-alanine and low affinity transport of $\gamma$-aminobutyric acid by a single transport system in cultured glioma cells. J. Biol. Chem. 254: 7076-7084.

McLennan, H. (1976) The autoradiographic localization of $L-\left[{ }^{3} \mathrm{H}\right]$ glutamate in rat brain tissue. Brain Res. 115: 139-144.

Miller, L. P., and D. L. Martin (1972) An artifact in the radiochemical assay of brain mitochondrial glutamate decarboxylase. Life Sci. 13: 1023-1032.

Morantz, R. A., W. Shain, and H. Cravioto (1978) Trauma and brain tumors: An experimental study. J. Neurosurg. 49: 84-92.

Nechay, B. R. (1977) Biochemical basis of diuretic action. J. Clin. Pharmacol. 17: 626-641.

Nicklas, W. J., and E. T. Browning (1983) Glutamate uptake and metabolism in C- 6 glioma cells: Alterations by potassium ion and dibutyryl cAMP. J. Neurochem. 41: 179-187.

Norenberg, M. D. (1979) The distribution of glutamine synthetase in the rat central nervous system. J. Histochem. Cytochem. 27: 756762.

Orlowski, M., and A. Meister (1970) The $\gamma$-glutamyl cycle: A possible transport system for amino acids. Proc. Natl. Acad. Sci. U. S. A. 67: $1248-1255$.

Ramu, A., C.-J. Pazoles, C. E. Creutz, and H. B. Pollard (1981) Catecholamine transport by isolated chromaffin granules. J. Biol. Chem. 256: 1229-1234.

Ribak, C. E., J. E. Vaughn, K. Saito, R. Barber, and E. Roberts (1976) Immunocytochemical localization of glutamate decarboxylase in rat substantia nigra. Brain Res. 116: 287-298.

Roberts, P. J., and P. Keen (1974) $\left[{ }^{14} \mathrm{C}\right]$ Glutamate uptake and compartmentation in glia of rat dorsal sensory ganglion. J. Neurochem. 23: 201-209.

Roberts, P. J., and J. C. Watkins (1975) Structural requirements for the inhibition of $\mathrm{L}$-glutamate uptake by glia and nerve endings. Brain Res. 85: 120-125.

Rosenthal, H. E. (1967) A graphic method for the determination and presentation of binding parameters in a complex system. Anal. Biochem. 20: 525-532.

Schousboe, A. (1981) Transport and metabolism of glutamate and GABA in neurons and glial cells. Int. Rev. Neurobiol. 22: 1-45.

Schousboe, A., and I. Divac (1979) Differences in glutamate uptake in astrocytes cultured from different brain region. Brain Res. 177: 407409 .

Schousboe, A., G. Svenneby, and L. Hertz (1977) Uptake and metabolism of glutamate in astrocytes cultured from dissociated mouse brain hemispheres. J. Neurochem. 29: 999-1005.

Schrier, B. K., and E. J. Thompson (1974) On the role of glial cells in the mammalian nervous system. Uptake, excretion, and metabolism of pulative neurotransmitters by cultured glial tumor cells. J. Biol. Chem. 249: 1769-1780.

Seligmann, B. E. (1978) Studies using molecular probes of membrane potential in glial cells and polymorphonuclear leukocytes. Ph.D. Dissertation, University of Maryland.

Stallcup, W. B., K. Bulloch, and E. E. Baetge (1979) Coupled transport of glutamate and sodium in a cerebellar nerve cell line. J. Neurochem. 32: 57-65.

Ticku, M. K., M. Ban, and R. W. Olsen (1978) Binding of $\left[{ }^{3} \mathrm{H}\right] \alpha-$ dihydropicrotoxinin, a $\gamma$-aminobutyric acid synaptic antagonist, to rat brain membranes. Mol. Pharmacol. 14: 391-402.

Van den Berg, C. J., and D. Garfinkel (1971) A simulation study of brain compartments. Metabolism of glutamate and related substances in mouse brain. Biochem. J. 123: 211-218.

Vogel, Z., A. J. Sytowski, and M. W. Nirenberg (1972) Acetyl-choline receptors of muscle grown in vitro. Proc. Natl. Acad. Sci. U. S. A. 69: $3180-3184$. 
Waniewski, R. A., and D. L. Martin (1981) Characterization of glutamate transport into cultured glioma cells. Soc. Neurosci. Abstr. 7: 697.

Waniewski, R. A., and D. L. Martin (1983) Selective inhibition of glial versus neuronal uptake of $\mathrm{L}$-glutamic acid by SITS. Brain Res. 268: 390-394.

Wheeler, D. D. (1979) A model of high affinity glutamic acid transport by rat cortical synaptosomes. A refinement of the originally proposed model. J. Neurochem. 33: 883-894.
Wolpaw, E. W., and D. L. Martin (1982a) Chloride transport in glioma cells. Trans. Am. Soc. Neurochem. 13: 134.

Wolpaw, E. W., and D. L. Martin (1982b) Sulfate transport as a model for chloride transport in glia cells. Soc. Neurosci. Abstr. 8: 238.

Wolpaw, E. W., and D. L. Martin (1984) $\mathrm{Cl}^{-}$transport in a glioma cell line: Evidence for two transport mechanisms. Brain Res. 297: $317-327$.

Zar, J. H. (1974) Biostatistical Analysis, Prentice Hall, Englewood Cliffs, NJ. 